\section{Another view of Vavilov}

SIR-There has been a tendency of late to lay the blame for Lysenko's ascent at N. I. Vavilov's door. Valery Soyfer is definitely of this opinion. I should like to draw attention to just a few of the discrepancies in his article "New light on the Lysenko era" (Nature 339, 415-420; 1989) which make it difficult to accept his view.

Let me begin with the All-Union Congress of Genetics, Plant and Animal Breeding held in Leningrad on 10-16 January 1929, where Lysenko first appeared before a representative forum of Soviet and foreign scientists. Soyfer makes much of the fact that Lysenko received an invitation to the congress and regards it as evidence of Vavilov's patronage (Vavilov was president of the congress). Yet in the congress proceedings (Vol. 1, pp 16-78) the names, addresses, place of work and occupation of all 1,500 or so of the participants are given. The Gandzha Plant Breeding Station, where Lysenko worked as senior specialist, was represented by a delegation of 21 people, from laboratory assistant to director; all of them, presumably, received the "prestigious invitation"

In his closing speech, Vavilov stressed that the congress was, indeed, an AllUnion one, in which every republic and all organizations doing research in genetics, plant breeding and animal breeding were represented. He made special mention of the fact that young researchers had taken an active part in the organization and in the work of the congress (Proceedings Vol. 1, pp 125-128).

Taking for granted that Vavilov played the chief role in Lysenko's advancement, Soyfer puts forward the following explanation for his motives. Vavilov, as director of the Institute of Applied Botany and New Cultures, had gathered a collection of seeds of wild and cultivated plants. He intended to use the collection to introduce new varieties of cultivated plants by transferring valuable genes to strains extant in the Soviet Union. But he did not know how to go about it (a strange supposition given that he had such outstanding scientists as plant physiologist N. A. Maximov and plant geneticist G. D. Karpechenko working in his institute). Soyfer writes: "Not himself an expert on plant breeding and without much experience of fieldwork, Vavilov could only hope the plan was feasible." The story goes that Vavilov and his colleagues encountered problems that could not be easily solved because of the differences in physiological requirements between foreign and local plants, when suddenly there came a man, Lysenko, who could solve a more complex problem - the conversion of winter crops into spring crops by cold treatment! Hence the "prestigious invitation" (to- gether with 20 other specialists of the Ganzha station). For over 60 years the world scientific community has been labouring under the delusion that Vavilov was one of the great scientists of the twentieth century, and an expert in plant breeding and fieldwork. Quite wrongly, Soyfer portrays Vavilov as a sort of babe in the wood, mesmerized by Lysenko and his work.

To "confirm this interpretation", Soyfer refers to an interview given by Vavilov to the Leningrad newspaper Smena, published on 11 January, in which he supposedly spoke of the idea of 'transformation' (whatever thay may mean). But the word 'transformation' was not even used. Smena featured several brief interviews with Vavilov and with a number of the congress participants, including the foreign guests. But there was no allusion to Lysenko or his work whatever.

Soyfer then points to an article in the newspaper Sotsialisticheskoye zemledelie (Socialist Agriculture) as though it were written by Vavilov himself - he gives the reference as "Vavilov, N. I. Sotsial. zemledelie, No 54 (616), p. 1 (24 February 1931)". But that was not an article by Vavilov. It was an account of Lysenko's report about his work in 1930 , which he made at a meeting of the presidium of the All-Union Academy of Agricultural Sciences, and the decision made by the presidium.

As further 'evidence' Soyfer selectively quotes a passage from Socialist Agriculture of 13 September 1931, an account of a meeting of the State Commissariat for Agriculture at which Vavilov spoke. But he cites only the part where Lysenko's work is favourably mentioned. This is the quotation:

Of special interest are the works of Lysenko who concretely approached [the problem] of changing late-ripening varieties into earlyripening ones, of transforming winter varieties into spring varieties. The facts he established are indisputable and of considerable interest. But it must be definitely said that tremendous collective work is required in order to elaborate concrete effective measures by means of which the vegetative period could be changed for practical purposes.

The sentence in italics was omitted.

According to Soyfer, "Only in 1936-37 did Vavilov realize what sort of person his protégé was". To support this contention, Soyfer had to find some favourable remarks about Lysenko's works that Vavilov had made at an earlier date. The reader is referred to what Vavilov said, supposedly in 1934, at a conference for planning genetics and breeding research. The reference given is: "Vavilov, N. I. Theoretical principles of the selection of plants. Moscow-Leningrad, Vol. p. 865 (1935)". But the conference was held on 25-29 July 1932, and the proceedings were published in 1933. Moreover, the work cited is a collection of articles in three volumes edited by Vavilov. Volume 1 features four long articles by Vavilov himself, but in none of them is Lysenko mentioned. The quotation used by Soyfer in fact comes from an article "Problems of the vegetative period" by L. P. Basova $e t$ al., who refer to Vavilov's report at the conference. This is a curious way of citing an author - not only out of context, but out of somebody else's paper. So much for the "new light on the Lysenko era" as far as Vavilov is concerned.

ELEANOR D. MANEVICH

Planetnaya 27, Apt 49,

125167 Moscow, USSR

\section{Ivory poaching}

SIR-I have recently returned from a hydrogeological mission to the arid and semiarid provinces of Kenya and have become better acquainted with the problem of the extermination of the elephants by the ivory poachers.

There are many measures to be taken and the Kenyan government is doing its best. After touring the areas through which the poachers come and smuggle the ivory, I can understand the tremendous difficulties of solving the problem. These areas are very scarcely populated by nomadic people and people coming from over the borders exploit this fact. They are also very well equipped to take their booty and disappear.

I would like to suggest some additional measures in order to save the elephants.

(1) Immediate measures: A special UN force should be mobilized in order to help the government to cope with the problem of poaching. I am sure that many volunteers from all over the world would be happy to join this force.

(2) Intermediate measures: Transfer elephants, in their thousands, to inland regions where they can be better protected from the poachers. This has to be carried out as an international effort, something like that mounted when the Aswan dam in Egypt was built and the archeological monuments were transferred. Such areas of refuge exist in the central Rift Valley provinces. Some of these areas are scarcely inhabited today.

(3) Long-term measures: Start an international programme of water development in the arid and semiarid regions bordering the savanas to give the people a safer and better source of income, thus eliminating the main cause for their need to take the risk of poaching.

ARIE ISSAR

Ben-Gurion University of the Negev,

Jacob Blaustein Institute

for Desert Research,

Sede Boker Campus 84990, Israel 